\title{
Reform and Re-invention in Public Higher Education
}

\author{
George M. Dennison
}

Published online: 8 January 2010

(C) Springer Science+Business Media, LLC 2009

\section{The Imperative for Reform}

For more than a decade, experts have warned of a widening gap between available revenue and rising costs associated with the array of programs Americans hold dear. The shock of the worst economic downturn since the Great Depression has provided new perspective on this warning. Few economists, if indeed any, predict a rapid recovery. At the same time, we must confront another and perhaps even more daunting challenge. Within the course of a few years, the United States has lost its preeminence in terms of the educational attainment of our citizenry, slipping to the second tier; and in all likelihood we will slip farther into the third tier unless we take action.

Higher education, however, has the opportunity to make a difference if those involved seize the moment and make the right choices, as President Gordon Gee of The Ohio State University noted in a recent keynote address to the American Council on Education (Gee 2009). To assure that desired outcome, they must revamp how they do their work, which will involve a great deal more than stressing student-centeredness, interdisciplinarity, and adequate funding. In brief, they must engage in reform and re-invention even as they accept the challenge of increasing the portion of American citizens with educational degrees from roughly 36 to 55\% (McPherson and Shulenburger 2009). That magnitude of change occurred during the $1960 \mathrm{~s}$, thanks largely to the creation of hundreds of community colleges. Does our society have the will to do it again?

George M. Dennison has served as President of The University of Montana for nineteen years and has worked in public higher education for forty years. He received the Ph.D. in History from the University of Washington in 1967 and held positions at the University of Arkansas, University of Washington, Colorado State University, Western Michigan University, and The University of Montana. President Dennison has published a book and several articles on American Constitutional History as well as a number of articles on public higher education.

G. M. Dennison $(\bowtie)$

The University of Montana, Missoula, MT, USA

e-mail: george.dennison@umontana.edu 
In a very real sense, those involved in higher education have a position at the epicenter of needed change, and what they do will directly affect the response of the states and nation to these challenges. More importantly, failure to act will result in either 1) change imposed from without or 2) the emergence of new institutions capable of responding to the needs of the society. It behooves them to seize the moment and lead a reform and re-invention effort. As Peter Facione said in his keynote address before the annual meeting of the Association of American College and Universities: "It is time for some straight talk — starting with the realization that institutions that cannot adapt, or that choose not to adapt, are going to fail" (Facione 2009, p. 24). In addition, I submit that no institution other than higher education has the capacity or the intellectual capital for such an undertaking; but those involved must move with dispatch and new thinking or find themselves left at the starting gate, irrelevant and unsupported.

What does reform and re-invention mean in this context? Definitions matter. Let me state at the outset that I do not subscribe to the simplistic notion that higher education can do more with less. However, I do believe higher education can become more efficient in using what it has, redirecting some current resources to pressing needs. I also accept the arguments of former Secretary of Labor Robert Reich that only by educating more American citizens, helping them to prepare for meaningful and productive lives in an increasingly interdependent, global, and technological society, and in the process revitalizing the middle class, can the United States reclaim its lost preeminence (Reich 2009). Higher education will need more resources to achieve the objective, but those involved can certainly improve the chances of securing more by putting what they have to the best possible use. To suggest some targets of opportunity, I will outline four reform and re-invention initiatives for higher education responses to the challenges.

- Engage Public K-12 Education: Since early in the last century, an ever widening chasm has separated K-12 education and higher education. Few will contend that higher education can do its part in response to the challenge of returning the United States to world educational leadership unless K-12 education does its part. We have learned from experience that we can achieve our mutual objectives only through collaboration.

- Rethink Undergraduate Education: Curricular reviews typically end by rearranging the chairs on the deck of the Titanic, resulting in relatively minor changes to lists of courses that satisfy an array of degree requirements with too little thought of how the parts relate to the whole. We must focus on the competencies we believe students need in the world of today, how we can engage the students in the self-development of those competencies, and how we can accurately assess success in this complex human undertaking, not on seat time or credits earned.

- Partner for Social and Economic Development: Higher education has earned recognition for its involvement with and engaging students in the community. The collaboration requires a range of activities from the maintenance of business incubators and technology transfer to targeted research to technical assistance to internships and the like. In addition, no one today argues with the proposition that desired cultural, social, and economic development depends upon the ready availability of robust, responsive, and seamless education programs, Pre-K-12 as well as higher education

- Model Best Practices for Efficiency and Effectiveness: In recent years, higher education has implemented "best practices" in its business operations, thereby freeing millions of dollars for internal reallocation. To date, too little of this effort has occurred 
in the academic sector. We must make every dollar go as far as possible as we identify ways to control and reduce costs.

These suggestions do not exhaust the possibilities but suffice to indicate the wide range of possible changes that will make a difference sooner rather than later if we seize the moment to implement them.

\section{The Voices of Experience}

To explore the terrain and suggest changes needed in higher education, specifically the American research university, I invited four experienced University leaders to peer into the future and propose new directions supportive of making the 21st century the "Century of the American Research University." As mentioned, President Gordon Gee challenged the research universities to rise to the occasion and bring about necessary reform and re-invention while helping to raise the educational attainment of American citizens. In a special report, the Association of Public and Land-Grant Universities warned that returning the United States to world leadership defined by the educational attainment of its citizenry will require the full engagement of all sectors of American higher education (McPherson and Shulenburger, Summer 2009). The four invited essays included in this issue of Innovative Higher Education offer insight into some of the changes the authors deem essential as the foundation for success.

President Steven Sample of The University of Southern California cautions about the perils of sacrificing broad-based education for life and leadership on the altar of work force preparation, i.e., readying people for the jobs and tasks of today rather than the challenge of creating the future. President Graham Spanier of The Pennsylvania State University echoes those concerns while emphasizing as well the essential necessity of 1) student centeredness, 2) a global orientation, and 3) the remarkably effective land-grant tradition of community out-reach and partnering. Chancellor William E. "Brit" Kirwan of the University System of Maryland surveys the history of the responsiveness of American higher education, taking note of recent threats as well as three new initiatives with the potential to make the difference. Finally, President Robert Bruininks of The University of Minnesota agrees with Chancellor Kirwan, but also offers counsel about the need for a new social compact to empower and enable higher education to meet the challenges before the society.

These essays provide real-world insights that will help to guide the reform and reinvention effort beginning across the country. Many in higher education will question the efficacy of another reform crusade, preferring to attend to the business at hand of educating students. Of course, the reform effort seeks to expedite achievement of precisely that goal and will have to involve "expansive thinking," as Nancy Cantor, Chancellor and President of Syracuse University, explains (Cantor 2009, 16-22).

In my view, those involved in higher education have no choice but to accept the challenge of reform and re-invention. While the public belief in the need for higher education has risen to an all-time high, the public perception of the responsiveness and quality of higher education has declined radically. Many if not most Americans believe that faculty members teach what they learned as they learned it, staff members do what they have always done as they have always done it, administrators promote calm and decorum to keep the money flowing, and students seek the shortest and least demanding route to a credential that will assure them a decent life style. Meanwhile, no one worries about the dysfunctionality of these disparate and contradictory approaches. Educators reject such a simplistic view, but perception counts for about $90 \%$ of reality. Until the 
perception changes, educators should not expect increased support for their efforts, however heroic.

I have enjoyed the honor and privilege to serve as the special editor for this issue of Innovative Higher Education, which focuses on presidential perspectives. I also want to extend my appreciation to Presidents Sample, Spanier, and Bruninks and Chancellor Kirwan. These senior higher education leaders made my task simple and rewarding. We all share a deep commitment to higher education and believe strongly in the strength and resilience of the American research university in response to the educational challenge of our time.

\section{References}

Cantor, N. (2009). A new Morrill Act: Higher education anchors the "remaking of America", American Council on Education. The Presidency, XII(3), 16-22.

Facione, P. A. (2009). Adaptive budgeting: Thirty-four ideas for raising revenues, cutting costs, retaining students, and saving jobs in hard times. Liberal Education, XCV(3), 24-31.

Gee, E. G. (2009). A call to (link) arms. American Council on Education. The Presidency, XII(2), 15-21.

McPherson, P., \& Shulenburger, D. (2009). Expanding undergraduate education to meet national goals: The role of research universities. An APLU Discussion Paper. Retrieved on August 25, 2009 from http:// www.aplu.org/NetCommunity/Document.Doc?id=1763

Reich, R. B. (2009). The great economic slowdown and a five-year look ahead. San Francisco, CA: CASE Summit for Advancement Leaders. 